\title{
NORTHERN NEIGHBOURS
}




\section{NORTHERN \\ NEIGHBOURS}

SCOTLAND AND NORWAY SINCE 1800

Edited by John Bryden, Ottar Brox and Lesley Riddoch

EDINBURGH

University Press 
(C) editorial matter and organisation John Bryden, Ottar Brox and Lesley Riddoch, 2015

(C) the chapters, their several authors, 2015

Edinburgh University Press Ltd

The Tun - Holyrood Road

I2 (2f) Jackson's Entry

Edinburgh EH8 8PJ

www.euppublishing.com

Typeset in I0.5/ I2.5 Ehrhardt by

Servis Filmsetting Ltd, Stockport, Cheshire,

and printed and bound in Great Britain by

CPI Group (UK) Ltd, Croydon CRo 4 YY

A CIP record for this book is available from the British Library

ISBN 978 o 748696208 (hardback)

ISBN 978 o 7486962 I 5 (webready PDF)

ISBN 978 I 474403436 (epub)

The right of the contributors to be identified as the authors of this work has been asserted in accordance with the Copyright, Designs and Patents Act I988 and the Copyright and Related Rights Regulations 2003 (SI No. 2498). 